\title{
Reading the Book of Revelation politically
}

\author{
De Villiers, Pieter GR \\ University of the Free State \\ pgdevilliers@mweb.co.za
}

\begin{abstract}
In this essay the political use of Revelation in the first five centuries will be analysed in greatest detail, with some references to other examples. Focus will be on two trajectories of interpretation: literalist, eschatological readings and symbolic, spiritualizing interpretations of the text. Whilst the first approach reads the book as predictions of future events, the second approach links the text with spiritual themes and contents that do not refer to outstanding events in time and history. The essay will argue that both of these trajectories are ultimately determined by political considerations. In a final section, a contemporary reading of Revelation will be analysed in order to illustrate the continuing and important presence of political readings in the reception history of Revelation, albeit in new, unique forms.
\end{abstract}

\section{Key words}

Book of Revelation; eschatological; symbolic; spiritualizing; political considerations

\section{Introduction}

Revelation is often associated with movements on the fringes of societies that are preoccupied with visions and calculations about the end time. ${ }^{1}$ The book has also been used throughout the centuries to reflect on and challenge political structures and

1 Cf. Barbara R. Rossing, The Rapture Exposed: the Message of Hope in the Book of Revelation (Westview Press, Boulder, CO., 2004). Robert Jewett, Jesus against the Rapture. Seven Unexpected Prophecies (The Westminster Press, Philadelphia, 1979). Richard Landes, "Introduction: The Terribles Espoirs of 1000 and the Tacit Fears of 2000", in Richard Allen Landes, Andrew Colin Gow, David C. Van Meter (eds.), The Apocalyptic Year 1000: Religious Expectation and Social Change, 950-1050 (Oxford University Press, Oxford, 2003), pp. 3-16. Also Allan A. Boesak, Comfort and Protest. The Apocalypse from a South African Perspective (Westminster Press, Philadelphia, P.A., 1987), p. 13. 
institutions. ${ }^{2}$ It thus played an exceptional and sometimes even radicalizing role in many societies across the globe in which it has been interpreted as a political document about a future kingdom that would bring the present evil, worldly kingdoms and powers to an end. ${ }^{3}$ Its violent contents, expressed in vengeful and pugnacious language, have intensified eschatological fervour. A close reading of these political receptions of Revelation promises to provide insight into the power of religious discourses in society and the church. In this essay, political use of Revelation in the first five centuries will be analysed in greatest detail, with some references to other examples. Focus will be on two trajectories of interpretation: literalist, eschatological readings and symbolic, spiritualizing interpretations of the text. Whilst the first approach reads the book as predictions of future events, the second approach links the text with spiritual themes and contents that do not refer to outstanding events in time and history. The essay will argue that both of these trajectories are ultimately determined by political considerations. In a final section, a contemporary reading of Revelation will be analysed in order to illustrate the continuing and important presence of political readings in the reception history of Revelation, albeit in new, unique forms.

\section{Eschatological readings of Revelation in early Christianity}

There are many examples of eschatological reception of Revelation in early Christian texts. This is not an unexpected development. Many of these examples can be explained as continuing and developing the eschatological proclamation of the historical Jesus and the expectation of an imminent parousia, which is also evident in Gospel texts. ${ }^{4}$ Latin exegetes like Justin Martyr (100-165), Irenaeus (130-200) and Victorinus of Petovium in the fourth century, are among many interpreters who understood the book's eschatology literally and linearly as predicting the future. ${ }^{5}$ For example,

2 For an overview of Revelation's influence on politics, cf. Harry O. Maier, Apocalypse Recalled. The Book of Revelation after Christendom (Fortress Press, Minneapolis, MI.), pp. 1-7.

3 Cf., e.g., Rev. 6:15: the kings of the earth, the rulers, the generals, the wealthy, the powerful, but also the extensive descriptions in Rev. 17-18. Further: Bernard McGinn, "Introduction: John's Apocalypse and the Apocalyptic Mentality", in R.K. Emmerson and B. McGinn (eds.), The Apocalypse in the Middle Ages (Cornell University Press, Ithaca, N.Y., 1992), pp. 3-20. Here: p. 14.

4 Cf. Everett Ferguson, The Early Church at Work and Worship. Vol. 2, Catechesis, Baptism Eschatology and Martyrdom (Cascade Books, Eugene, OR., 2014), pp. 213-243. He notes (p. 213), 'Eschatological hope was strong and central to early Christian existence.'

5 For a full discussion of these interpreters and for references, cf. Kevin L. Hughes, Constructing Antichrist: Paul, Biblical Commentary, and the Development of Doctrine in the Early Middle Ages (The Catholic University Press, Washington D.C., 2005), pp. 29, 30-32. He notes (30-32) how Irenaeus through numerological calculations speculates about possible candidates, but does not identify a particular person, whilst 
they interpreted Rev 20:4-5 as predicting a thousand-year reign of believers, believed that Revelation 20-21 refers to the coming of a concrete, earthly Jerusalem, and speculated about the identity of the Antichrist and the number 666 mentioned in Revelation 13:18. This eschatological reading of Revelation has to a large extent been determined by specific historical conditions of uncertainty and anxiety, and by periods of transition when communities felt alienated by their circumstances and found consolation in their hope on the future. Almost all of the earliest authors were victims of Roman oppression and even persecution. The eschatological pronouncements of Victorinus, for example, who was martyred in 303, reflect his experiences during the persecution of Emperor Diocletian. He regarded Rome as Babylon. Similarly, Irenaeus identified the number 666 as Latinus and Rome, that is, as those 'who reign now' (Adv. haer. 5,30).

\subsection{Systematizing eschatological expectations}

The expectation of the end time was so seminal to early Christian authors that they searched their sacred sources for more information. Their attention was drawn to Revelation's dynamic interaction with texts like Daniel, which describes patterns and phases of future events, and they began to read Revelation through the lens of these patterns. This study initiated an important new phase in the book's reception history.

One outcome was a complex chronological schema. Irenaeus (e.g. in Adv. haer. 5, 30-35), Tertullian (e.g. in Adv. Marc. 24) and many others distinguished between various parts or phases of world history. The general pattern includes elements like a cosmic history of seven ages, a Sabbath of creation, four empires ending with Rome, Rome's decline into ten kingdoms, a seven-year rule by the Antichrist, the appearance of two prophets, persecution of the church, the parousia, a resurrection and a millennial kingdom. This schema reflects Revelation's description of world events, for example in Revelation 6, which describes events in terms of seven seals, the first four of which are seen as referring to four successive periods,

Hippolytus portrayed him as of Jewish origin, as rebuilding the temple in Jerusalem, gathering disciples and sending them out, restoring the Roman Empire and persecuting Christianity. Hughes concludes (30), "Irenaeus, Hippolytus, Lactantius, Tertullian, indeed nearly all of the early Fathers had a vivid sense of the imminent end, and many subscribed to millenarian versions of Christ's return". 
followed by a more extensive fifth seal, and then a sixth seal representing the penultimate phase before history is consummated at Christ's return. This systematization is also found in the other septets in Revelation (Rev $8-9$; 14). ${ }^{6}$ In Revelation 20 the coming of the Antichrist is followed by a millennium and a last struggle before the final judgment takes place and the kingdom of God appears. ${ }^{7}$

This schema was significantly influenced by chronologies that were already popular and well-known in the Greco-Roman world. ${ }^{8}$ The chronologizing of Revelation's pronouncements can be traced to Julius Africanus (ca. 160-240), ${ }^{9}$ whose work influenced Hippolytus and Lactantius in the third century, as well as many other Greek and Latin authors. ${ }^{10}$ These authors designed a world calendar that placed the end of the world in the year 500 $\mathrm{CE}$. The calendar covered 6000 years, based on the six days of creation mentioned in Genesis 1, with one day representing 1000 years. ${ }^{11}$ The incarnation was set in the year 5500, which was thus 500 years before the end. ${ }^{12}$ After 6000 years, Christ's parousia would take place, followed

6 Adler indicated that the roots of such Christian surveys can be traced to the apocalypse of 70 weeks in Daniel 9:24-27 which is a revelation of an angel to Daniel about the course of future history. Cf. William Adler, "The Apocalyptic Survey of History Adapted by Christians: Daniel's Prophecy of 70 Weeks", in James VanderKam and William Adler (eds.), The Jewish Apocalyptic Heritage in Early Christianity. Compendia Rerum Judaicarum ad Novum Testamentum, Section 3. Jewish Traditions in Early Christian Literature (Van Gorcum, Assen; Minneapolis, MI., Fortress Press, 1996), pp. 201-237. Here: p. 202.

7 For a discussion of Revelation's eschatology and of different interpretations of its millennialism, cf. Ferguson, Early Church, p. 218.

8 Cf. the discussion in J.A. Cerrato, Hippolytus between East and West: Provenance of the Corpus (Oxford University Press, Oxford, 2002), pp. 236-237. For chronology in Daniel, cf. James Taborn, "Ancient Jewish and Early Christian Millennialism", in Catherine Wessinger (ed.), The Oxford Handbook of Millennialism (Oxford University Press, Oxford, 2016), pp. 152-267, here: p. 256.

9 Cf. the various essays on Africanus and his chronicle in Martin Walraff (Hrsg.), Julius Africanus und die christliche Weltchronik (Walter de Gruyter, Berlin, New York, 2006). Africanus was the author of the Five Books of Chronology.

10 Martin Wallraff, (ed.), Iulius Africanus Chronographiae. The Extant Fragments (De Gruyter, Berlin, 2007), XXXIV, notes that despite discussions over the last four centuries, there is no consensus about the contents of Africanus' chronology.

11 Ferguson, Early Church, 216, notes the influence of Ps.90:4 and refers to 2 Pet.3:8 on this interpretation.

12 Adler, Historians, 591. There were also other chronographies, like that of Hippolytus and Quintus Julius Hilarianus. 
by a Sabbath rest of a thousand years. The authors offered extensive and often sophisticated arguments for their calculations. ${ }^{13}$ The intellectual nature of these debates is attested by Eusebius, who notes his profound respect for the person and work of Julius Africanus, although he criticizes Africanus' methodology and calculations. Eusebius describes Africanus' Chronographiae as the work of a learned, cultivated person and as a monument of accuracy and diligence. ${ }^{14}$

This appropriation of chronographies was motivated by political considerations. The appropriation, for one, began when Christians were persecuted by the state because they were accused of belonging to a 'new' religion, which meant that their loyalty to the state was being questioned and they were sometimes regarded as revolutionaries. In response to this serious accusation, some Christians defended themselves by stressing the antiquity of their beliefs and, therefore, the legitimacy of their faith. ${ }^{15}$ They offered chronographies showing that their religion had a long history. These chronographies shared with their Greek counterparts an extensive interest in past history, a golden era of incorruptibility. This past had been lost and deformed as a result of human decadence and corruption among humanity. The implication was that anything that was part of this golden era was seen as representing authenticity, veracity and incorruptibility. ${ }^{16}$ The major differences between Christian and Greek chronographies

13 Chronographies were highly regarded by authors like Justin Martyr, Tatian, Theophilus, Tertullian, Clement of Alexandria and others. Cf. the discussion in Richard W. Burgess, Apologetic and Chronography. The Antecedents of Julius Africanus, in Walraff, Julius Africanus, pp. 17-43. Here: p. 29.

14 Cf. William Adler, "Eusebius' Critique of Africanus", in Walraff, Julius Africanus, and pp. 147-160. Umberto Roberto, "Julius Africanus und die Tradition der hellenistischer Universalgeschichte", in Walraff, Julius Africanus, pp. 3-16, describes the widespread phenomenon of world histories in Antiquity, the resurgence of such histories since the beginning of the third century as a result of the interaction of Christianity with its Hellenistic context and the high culture that is reflected in them. Despite continuity, he stresses the Christian nature of chronographies since Africanus: his chronography is 'von der revolutionären Botschaft des Christentums geprägt' (4). Note especially his description of the exceptional career of Africanus. For the learned nature of apocalyptic eschatology, cf. Ferguson, Early Church, 214.

15 Burgess, Apologetic, 29. Ferguson, Early Church, 229, refers to texts about a future, heavenly kingdom (vis-à-vis an earthly one), as an apologetic attempt to allay fears by authority about a revolutionary Christianity.

16 Roberto, Julius Africanus, 5, describes how the quest for truth is also at work in Africanus' chronography. 
was that Christians characterized the past as a divine plan unfolding in history, and claimed not only to know about the past, but also to have been granted reliable insight into the future. This future was also part of the unfolding divine plan, which was leading toward the parousia as its ultimate purpose and consummation. One pertinent example is, as Adler pointed out, the chronography of Theophilus, bishop of Antioch (Autoleg 3). ${ }^{17}$ Such, broadly speaking and without ignoring many individual views, were the arguments used to legitimize the Christian faith vis-à-vis political authorities and opponents. ${ }^{18}$ One can also detect a more covert political function: the chronographies proved to outsiders and political opponents that Christianity was superior to other pagan religions. Furthermore, one should not underestimate the religious function of these chronographies: they were also drawn up in anticipation of the parousia. ${ }^{19}$

Chronologies had further political functions. ${ }^{20}$ While they held on to the belief in a literal end of the world, they were also used to polemicize against imminent or earthly expectations that had dangerous political consequences. Such expectations sometimes caused rebellion, instigated by some radical groups who wanted to help bring about the end or to remove political opponents that they regarded as instruments of evil. ${ }^{21}$ Church leaders who were apprehensive about such groups stressed that chronologies indicated that the end time was still far away, often with reference to the year 500. Rather than engaging in dangerous speculations, Christians were

17 Cf. William Adler, "Early Christian Historians and Historiography", in S.A. Harvey and David C. Hunter (eds.), The Oxford Handbook of Early Christianity (Oxford University Press, Oxford, 2008), pp. 584-602 (587-588).

18 Cf. Arthur J. Droge, Homer or Moses? Early Christian Interpretations of the History of Culture (J.C.B. Mohr (Paul Siebeck) Verlag, Tübingen, 1989). For an extensive discussion and examples.

19 Adler, Historians, 598: 'From the outset, millennialism, the demands of apologetic, and a supreme confidence in their sources pitted Christian historians against their pagan counterparts. This was the result of the extraordinary interest in the world chronology that was designed at an early stage, mostly to anticipate the return of Christ.'

20 Cf. Adler, Apocalyptic Survey, 201. Richard Landes, "Lest the Millennium be Fulfilled: Apocalyptic Expectations and the Pattern of Western Chronography 100-800 CE", in Werner Verbeke, Daniel Verhelst and Andreas Welkenhuysen (Hrsg.), The Use and Abuse of Eschatology in the Middle Ages ML.St 15 (Peeters, Leuven, 1988), pp. 137-211.

21 Ferguson, Early Church, p. 214, notes that those who 'acted in some aggressive manner to hasten the action in the divine drama,' were in a minority. 
to await the end patiently. ${ }^{22}$ An example is found in Eusebius (H.E. 6.7). He describes a chronology by a certain Judas, ${ }^{23}$ who interpreted the seventy weeks of Daniel as having already been fulfilled. This convinced him that the coming of the Antichrist was imminent and would occur in his own time, the third century. Eusebius notes the consequences of such literalist expectations, describing with disdain the hysteria it created among Christians in Alexandria and their subsequent persecution by Emperor Septimius Severus (r. 193-211 CE). He notes that this persecution disturbed the minds of many. It is noteworthy that Revelation was still linked with a literal expectation of the future by those critical of such hysteria, who emphasized that the anticipated future was still far off.

\subsection{Eschatological fervour as a pervasive presence}

Expectations of the end continued to be pervasive in later Christianity, as examples from key areas reveal. These include seminal elements from Revelation, like the expectations of the parousia, the return of Jerusalem, and a thousand-year reign before the ultimate end of the world. ${ }^{24}$

The expectation of the end was characteristic of the Montanist or New Prophetic Movement, which originated in Phrygia around 150 and is known for its intense interest in ecstatic prophecy and visionary experiences. Montanus, the initial leader, announced the imminent end of the world. This movement paired expectation of the end with a rigid, moralistic asceticism, but, again, with political consequences: Adherents of the movement were convinced of the temporary nature of the existing, corrupt world with its evil rulers that would come to an end with the parousia of Christ. They expected Revelation to be fulfilled literally in their own time and context, even anticipating that the heavenly Jerusalem would

\section{Adler, Historians, p. 598.}

23 Jerome also mentioned the chronography of Judas and his prediction of the Antichrist's coming in his own time. Cf. Cerrato, Hippolytus, p. 21.

24 P. Fredriksen, "Tyconius and Augustine on the Apocalypse", in R.K. Emmerson and B. McGinn, The Apocalypse in the Middle Ages (Cornell University Press, Ithaca, N.Y., 1992), p. 21, observes how Christians generally, but 'especially those in North Africa, had on the authority of the Apocalypse asserted an enthusiastic and socially disruptive millenarianism.' 
descend on a plain between the towns of Tymion and Pepuze in Phrygia. ${ }^{25}$ Their criticism was also directed against church authorities. This antipathy made them unpopular with these leaders and their political allies, resulted in their being branded as heretics. They were finally banned by Emperor Justinian I in the sixth century.

A similar group were the Donatists in North Africa, who came into existence after persecutions by Emperor Diocletian at the end of the fourth century. Critical of the church and emphasizing a pure, moral lifestyle, they expected the imminent coming of an earthly kingdom. ${ }^{26}$ They distanced themselves from Catholic clergy, whom they criticized for collaborating with the Roman Emperor. They regarded themselves as martyrs and as the elect remnant because, as outlined in Revelation, they faced the hostility of Rome and suffered persecution by the imperial authorities. Even where the end was expected in the distant future, it was used to keep literal expectations of a coming end of the world alive.

Their eschatological fervour was not unique, though. In the year 397 the Catholic bishop Hilarianus, who was part of the church that the Donatists rejected, drew attention to the year 500 which, he warned, was only a century away. Fredriksen notes how the bishop's remark illuminates the political ramifications of eschatological expectations: 'If Catholics thought this way, and they had the empire on their side, how much more so the Donatists, who "beneath the purple and scarlet robes of the apocalyptic whore... could still recognize Rome". ${ }^{27}$ This example illustrates the widespread and pervasive presence of eschatological expectations in these regions and their link with a literal, eschatological understanding of Revelation. Augustine refers to an acute awareness of the end time among some such groups in his own time in De excidio urbis 6.7. He narrates an episode in $398 \mathrm{CE}$, when crowds in

25 Philip Schaff, The Christian Church from the $1^{\text {st }}$ to the $20^{\text {th }}$ Century (Delmarva Publications, 2015), describes the Montanists as 'the warmest millennarianists in the ancient church.' For the eschatological interests of the Montanist, cf. Margaret R. Miles, Rereading Historical Theology: Before, During, and After Augustin (Cascade Books, Eugene, OR., 2008), pp. 79-80 and Ferguson, Early Church, 223. Charles Evan Hill, Regnum Caelorum: Patterns of Millennial Thought in Early Christianity (Eerdmans, Grand Rapids, 2001), pp. 143-159 questions whether the Montanists had an imminent millennial outlook.

26 For the origins, identity and persecution of Donatists, cf. Miles, Rereading, pp. 80-84.

27 Fredriksen, "Tyconius and Augustine", p. 23. 
Constantinople panicked after seeing portents they thought represented signs of the end. Several other such events were reported elsewhere so that Fredriksen can conclude, "The years of Augustine's episcopacy coincided with a stream of apocalyptic due dates and events, both within Africa and beyond." ${ }^{28}$ The above examples show how marginal groups on the fringes of Christianity and the church who opposed the ecclesiastical and political status quo, reflect literal readings of Revelation and of the imminent end of the world.

The fall of Rome further influenced eschatological readings of Revelation in 410 CE when Alaric, leader of an army of Visigoths (390-410 CE), sacked Rome. Later, he defeated Augustulus, who was the last emperor in the West. Once again these literal readings had political ramifications. For some groups that expected an imminent end, this defeat confirmed Revelation's prophecies about the destruction of Rome. They were strengthened in this belief by a series of natural disasters and unusual phenomena that were traditionally associated with the imminent end. The closeness of the year 500 also contributed to their eschatological fervour, reflecting the lingering influence of Africanus' chronological calculations: "Thanks to the popularity of Africanus' calculations, the reign of Anastasius thus became a time of intense eschatological speculation." ${ }^{29}$ This date also coincided with the reign of a Byzantine Emperor named Anastasius (i.e., Resurrection), a name that many considered to be a sign of the end times. As a result of all these developments, the end was predicted for, e.g., the years 491 and 507/508. ${ }^{30}$ Revelation was linked with a literal end that would happen at the end of the century.

28 Fredriksen, (ibid., p. 29) refers to research on this matter and instances where Augustine discussed predictions of the end.

29 Cf. Burgess, Apologetic, p. 32.

30 Several other documents reflect this heightened eschatological tension, such as the socalled Tübinger Theosophie (474/75 - 476-491), the Oracle of Baalbek (510), the Greek Vorlage of an Armenian Apocalypse and The seventh vision of Daniel ( $5^{\text {th }}-7^{\text {th }}$ century). Each one of them reflects or contributes to the intense anxiety and high expectations that existed in these times. Cf. Mischa Meier, „Eschatologie und Kommunikation im 6. Jahrhundert n. Chr. - oder: Wie Osten und Westen beständig aneinander vorbei redeten", in Wolfram Brandes and Felicitas Schmieder (Hrsgg.), Endzeiten. Eschatologie in den monotheistischen Weltreligionen. Millennium-Studien zu Kultur und Geschichte des ersten Jahrhunderts n. Chr. 16 (De Gruyter, Berlin/New York 2008), pp. 41-73, especially p. 49. 
Such literal readings of Revelation were held in contempt. Augustine, for example, wrote disparagingly in De Civitate Dei 20.7 about the "ridiculous fancies" of those who read Revelation 20:1-6 literally. ${ }^{31}$ This response should not lead us to conclude that they were driven purely by political motives or necessarily lacked religious devotion as is clear when Augustine, who strongly opposed literalism, writes that he himself once read Revelation 20:1-6 as a literal description of a first, bodily resurrection that would inaugurate a thousand years of sabbatical rest for the saints. Even though he had since given up this conviction, he underlines that this literal understanding had nothing to do with extravagant debauchery or lewd behaviour that some associated with the end. For him, the exuberant cult of the dead at that stage meant celebrating the resurrection and joyfully awaiting a good future. In the merriment that accompanied the cult of the dead, for example, one could recognize the "ancient Christian hopes for life after the primo resurrectio, an affirmation that when the kingdom came, status distinctions would dissolve, life would be joy, labours would cease, the earth would yield its fruits in abundance, and God would wipe away every tear." 32

The reception history of Revelation confirms how pervasive these early speculations in the first five centuries about the future were in later times, ${ }^{33}$ as McGinn has noted. He describes how such speculations were revived by the teachings of Joachim of Fiore (1135-1202), who increased their popularity in the Middle Ages. ${ }^{34}$ Joachim predicted a future reign on earth after the coming of the Antichrist, which he described as the monks' age

31 Cf. further below for a similar attitude of Eusebius. Such contempt is to be seen also on a meta-level in work of contemporary researchers who were apprehensive about apocalyptic literature. Their prejudices against apocalyptic literature and movements, made them ignore or minimize the phenomenon of future expectations and predictions. As a result, scholarly works failed to do justice to material that attested to the existence of literal eschatological readings of Revelation. Cf. the various essays in Richard Allen Landes, Andrew Colin Gow, David C. Van Meter (eds.), The Apocalyptic Year 1000: Religious Expectation and Social Change, 950-1050 (Oxford University Press, Oxford, 2003), but especially the contribution of Landes, Introduction, pp. 3-16, who writes extensively about this phenomenon in French scholarship.

32 Fredriksen, "Tyconius and Augustine", p. 24.

33 Cf. the extensive and original discussion of millennial expectations in Ferguson, Early Church.

34 McGinn, “Introduction,” p. 4. 
of peace. McGinn observes that the "horizontal or historically apocalyptic dimension of the book could never be totally expunged, even by the most ingenious of purely ecclesiological or moral readings. It remained, not lurking under the surface of the text but rather openly in the structure and symbols of the book, for those, like Joachim of Fiore, who had the eyes to see it." ${ }^{35}$

McGinn's remark is confirmed by other developments after Augustine's rejection of literal readings, such as the First Crusade to Jerusalem at the end of the first millennium, in which pilgrims participated because they expected the coming of the end in the physical Jerusalem. In 1096 CE, 100,000 "warriors, priests, women, poor folk, bishops, prophets and a few children left homes in France, Italy and Germany and marched to Jerusalem". ${ }^{36}$ Although many participated for material gains and rewards, or because they had been promised absolution from sins, Rubenstein has argued that one important motivation for the trip to Jerusalem was the pious conviction that the crusade could set the events of the Apocalypse in motion and fulfil biblical prophecies predicting Christ's final battle in Jerusalem. People were thus helping to bring about the Apocalypse, the final battle between good and evil that would inaugurate the end of the world. ${ }^{37}$ The earthly Jerusalem was the place to be because the end of time and Armageddon were imminent.

In its later reception history, Revelation continued to be interpreted as spelling out events that will take place in history and time. Such eschatological readings experienced a new peak among fundamentalist groups at the end of the second millennium. This new phase continued

35 McGinn, Introduction, pp. 18-19. On Fiore's elaborate calculations and divisions of history into epochs, cf. Cf. Robert G. Clouse, “The Danger of Mistaken Hopes”, in Carl E. Armstrong, W. Ward Gasque (eds.). A Guide to Biblical Prophecy (Wipf and Stock, Eugene, OR., 2001), 29-30. Fiore's systematizing depended on passages like Revelation $11: 3 ; 12: 6$ and $14: 6$ which texts he read in the light of political entities and events of later times.

36 Jay Rubenstein, Armies of Heaven: The First Crusade and the Quest for Apocalypse (Basic, New York, 2011), p. xii.

37 Cf. A. Nemeroff, Apocalypticism and the First Crusade. [Online:] Retrieved from https:// sites.dartmouth.edu/crusadememory [2016, 20 November], who writes, 'Being a part of a divine event and helping to bring about the Apocalypse was a far more compelling reason to go on the journey to Jerusalem than many of the other common reasons cited today.' 
the same interpretive trajectory, but had a special character because it was intertwined with contemporary political realities. The 'Left Behind' movement spread like wildfire across the globe through the best-selling publications of authors and preachers like Hal Lindsey, Tim LaHaye (who wrote sixteen Left Behind books that have sold more than 80 million copies), Jack Van Impe and John Hagee. This movement promotes a literal, dispensational schema based on Revelation 20. According to this schema, a select group of 'true' believers will be raptured to heaven. After the rapture, those who are left behind on earth will suffer tribulation for a period of seven years, under attack by the Antichrist's evil forces. During this period a gathering of nations will take place in the Middle East to wage war over Jerusalem. The parousia will take place when the nations have been defeated. Satan will be set loose to wage war. The ultimate end will begin with the reign of Christ, after the final eradication of evil. ${ }^{38}$

These later contemporary readings of Revelation in Left Behind circles are driven by political convictions and promote an activist political agenda, e.g., regarding the United States' policies on Israel. ${ }^{39}$ The battle of Armageddon is linked with the establishment of the Jewish state in 1948 and the recapture of Jerusalem in 1967. These events are regarded as signs of the imminent end and as confirmation of God's unfolding plan. They prepare the way for rebuilding the Jewish temple and for Christ's parousia ${ }^{40}$ when the final battle for Jerusalem will take place. The fate of

38 A standard analysis of the many forms of end expectations is found in Court (1979). Cf., for example, G.K. Beale, The Book of Revelation. NIGTC (Eerdmans, Grand Rapids, MI., 1999), pp. 44-54. Well-known, however, is how these expectations multiplied into so many forms that it has become conventional to distinguish at least four approaches (with endless variations within each one of them). There was a preterist view (which interprets Revelation as referring to events in its own time), a historicist view (viewing Revelation as pointing towards events that are unfolding during the course of history), a futurist view (explaining Revelation in terms of a future events before the end of the world) and an idealist view (its symbols represents timeless truths). Among these, the futurist view debated various forms of the millennium (described in Revelation 20:1115) that will accompany the appearance of Antichrist and the mortal combat between his armies and the faith community.

39 Cf. the extensive, well-documented and sometimes disconcerting discussion in Rossing, Rapture.

40 Paul S. Boyer, "John Darby meets Saddam Hussein: Foreign policy and Bible". The Chronicle of Higher Education 13 February 2003: B10-11, describes how this movement permeated the highest levels of policy making, as can be seen in apocalyptic language 
Israel is thus a major priority in these circles. The disconcerting aspect of this reading, is that the unconditional support for the state of Israel shows little awareness of political complexities, or concern about Israel's discriminatory practices and the fate of Palestinians (including Palestinian Christians). It is, furthermore, illustrative of the violent nature of Left Behind readings. Extreme violence in the Middle East plays a vital role in their eschatology, and God's plan and the parousia are made conditional on war and the destruction of unrepentant Jews. ${ }^{41}$ According to LaHaye, for example, Jesus did not promise peace, but the sword: he is Revelation's violent warrior against evil (Rev. 21), who will literally and physically eliminate all opposition.

Also striking is the way in which this reading ties in with cultural wars in the United States. The movement's negative and judgmental attitude discovers evil everywhere, even in the United Nations and its Secretary General, who are regarded as representatives of the Antichrist because they seek to promote world peace. Similarly, any politician who aims to eliminate economic inequalities, end poverty, campaign for disarmament, promote family planning or campaign for minority rights is regarded as representing evil. ${ }^{42}$ The Left Behind movement has a comprehensive sociopolitical agenda, is pessimistic about existing socio-political structures and does not shy away from advocating or approving of violence that would bring about inconceivable destruction and immeasurable suffering to many people, including those from Christian contexts who do not share their particular religious convictions and context. ${ }^{43}$

of the then President Bush against Saddam Hussein. Bush, whose speech writer was an Evangelical, regarded Iraq as a serious threat.

41 Richard Landes, "Introduction: The Terribles Espoirs of 1000 and the Tacit Fears of 2000", in Richard Allen Landes, Andrew Colin Gow, David C. Van Meter (eds), The Apocalyptic Year 1000: Religious Expectation and Social Change, 950-1050 (Oxford University Press, Oxford, 2003), pp. 3-16. He draws the line from this era to the betterknown nineteenth millenarians like the Millerites, Russelites, Darby, and Scofield and, in the twentieth century, John Walvoord, Charles Ryrie, Hal Lindsey, Tim LaHaye and Joel Rosenberg.

42 Cf. the extensive documentation and examples of such convictions in various novels of the Left Behind movement by Crawford Gribben, Writing the Rapture; Prophecy Fiction in Evangelical America (Oxford University Press, Oxford, 2009), pp. 129-144. Also informative about these examples and the cultural wars that inform them, is Rossing, Rapture.

43 Cf. Gribben, Writing, for the violent nature of the Left Behind readings. 


\section{Spiritualizing readings of Revelation as counter-strategy}

As briefly noted above, throughout the centuries, some voices have rejected the literal approach to Revelation. From an early stage these critics have offered an alternative approach that focusses on Revelation's meaning in terms of spiritual themes and matters. Such readings detached its meaning from predictions about the future. This different trajectory began to develop at a time when Christianity was becoming increasingly distanced from its Jewish roots, accompanied by drastic changes to Christianity's political situation. As Christianity was transplanted into new areas and societies, its followers were compelled to reflect on the relevance of the Bible for new contexts and for Jewish groups who did not embrace Christianity. ${ }^{44}$ Especially influential in developing an alternative reading of Revelation were two theologians from Alexandria in the second half of the second century. Clement and Origen regarded literal readings as too crude and too 'Jewish' and defended a spiritual approach to the book. ${ }^{45}$ They adopted Greek reading strategies that complemented a first careful reading of the text with an allegorical explanation. Origen thus interpreted Revelation as an allegory of the church's spiritual struggle against evil (De Princ. 2.11.23). Evil included not only the initial Jewish resistance to the historical Christ, but also continuing opposition to and struggle against the church.

On closer investigation, it is clear that this spiritual reading was driven by political power games that had to do with the changing relationship

44 Cf. for the dynamics of the Greek-Jewish interaction, Gerhard Maier, Die Johannesoffenbarung und die Kirche. WUNT 25 (J.C.B. Mohr, Tübingen, 1981), 93. For references to the hostile attitude of Early Christianity towards Jewish groups, cf. Ralph W. Klein, "Anti-Semitism as Christian Legacy: The Origin and Nature of our Estrangement from the Jews". Currents in Theology and Mission 11 (1984): 285-301 (291-292); S. Mark Veldt, "Attitudes toward the Jews in the Earliest Centuries A.D"., 2007. Dissertations. Paper 925. [Online] Available: http://scholarworks.wmich.edu/cgi/ viewcontent.cgi?article=1927\& context=dissertations [Accessed 24 February 2017].

45 This view of literal readings of Revelation as Jewish, is found, for example, in Origen, followed by Methodius of Olympus, Lactantius and Dionysius of Alexandria. Cf. Bernard McGinn, "Introduction: John's Apocalypse and the Apocalyptic Mentality", in Richard K. Emmerson and Bernard McGinn (eds.), The Apocalypse in the Middle Ages (Cornell University Press, Ithaca and London 1992), pp. 3-19, here p. 17. Cf. also Cross, Faith, p. 264. For an overview of Origen's attitude towards Judaism, but also his harsh criticism that they were responsible for Jesus' death and had a superficial, naïve and carnal knowledge of Scripture that was superseded by Christianity's spiritual interpretation, cf. Veldt, Attitudes, pp. 233-266. 
between state and church, especially after the conversion of Constantine. This affected a literal reading of Revelation's contents and symbols. Emperors who embraced Christianity and had co-opted church leaders, could no longer be equated with figures from Revelation. Eusebius of Caesarea ( $4^{\text {th }}$ century) offers special insight into this radical change. It is telling that he thought it necessary to write two publications that reflected his positive attitude towards the political powers of his time. In his Life of Constantine and Praise of Constantine, he expresses admiration for the reign of Constantine in glowing terms. In Life of Constantine 1.3-1.4, he describes Constantine as the only Roman Emperor who had also been a friend of God, and praises him exuberantly for 59 chapters with a list of examples about his virtuous life. Eusebius expresses this praise in biblical language, cites prophetic texts as proof and even compares Constantine with key biblical figures like Moses.

This positive appraisal of Constantine forms the framework for his interpretation of Revelation 20. Eusebius distances himself from literal readings of Revelation. Its criticism of Rome is no longer valid. His disdain is clear from his description of Papias' teaching about an earthly kingdom of Christ as a reign of thousand years after the resurrection of the dead (H.E. 3.12), which he calls "mythical things". Such literal readings of the Bible are the result of Papias' "limited understanding" of the "mystical" nature of such expectations (H.E. 3.12-13; 3.39.12). ${ }^{46}$ In contrast, Eusebius interprets Revelation 20 spiritually, like Origen before him. It does not speak about a future kingdom, but about a spiritual condition of the church. His reading is at the same time also political. The millennium had not started with the incarnation, as some thought, but with the time of Constantine which represents the peaceable kingdom in which the church participated. This was a time in which there was no war or persecution of the church. ${ }^{47}$

46 In E.H. 3:28 Eusebius links millennialism with a heresy taught by Cerinthus about the kingdom of Christ that will be an earthly one characterized by licentious and lewd behaviour.

47 L.C. 8.9. Hughes, Constructing, p. 33, noted how the church's positive relationship with the state changed for the worse under the reign of Julian (361-363). This caused much anxiety and led to the resurgence of eschatological thinking. Ferguson, Early Church, p. 230. Cf. also W.J. van Asselt, "Chiliasm and Reformed Eschatology in the Seventeenth and Eighteenth Centuries”, in: A. van Egmond \& D. van Keulen (eds.), Christian Hope in Context. Studies in Reformed Theology. 4 (Meinema, Zoetermeer, 2001), pp. 11-29. 
In the history of reception, Augustine (d. 430), following Tyconius (370/390), exerted the greatest influence on spiritual readings of Revelation. Under the influence of Origen, he read the text in terms of historical and contextual information, but proceeded to a figurative and finally a 'mystical' or spiritual exegesis. ${ }^{48} \mathrm{He}$ argued (De Civ. 20.7) that Revelation's eschatological formulations had been fulfilled by the death and resurrection of Christ. The future reign of Revelation 20 had nothing to do with an earthly kingdom, but rather symbolized the turbulent times the church would face between the advent and parousia of Christ. Although an end to the present traumatic situation would come, the millennium was a present reality. Ultimately, then, Revelation had to do with a spiritual struggle between good and evil and is not to be read as predictions of future events.

Oecumenius' Greek commentary on Revelation provides another example of how a new political context brought about a spiritual reading of Revelation. Like Africanus, he was a well-educated and informed author. ${ }^{49}$ He wrote in the sixth century, shortly after the year 500. His comments on Revelation are characterized by an apologetic intention to counter revolutionary groups who had been using calculations of the end to stoke rebellion against the state, as well as a desire to explain its deeper, nonliteral meaning. ${ }^{50}$ Oecumenius retains a literal interpretation of Revelation up to a certain point. He accepts the parousia, the resurrection of the body

For Eusebius's relationship with Constantine, cf. Benjamin David Brandon, Eusebius of Caesarea's Oration in Praise of Constantine as the Political Philosophy of the Christian Empire. (M. A. Thesis, Boise State University, December 2012).

48 Cross, Faith, 265. Cf. further William C. Weinrich, Revelation. Ancient Christian Commentary on Scripture 12 (Intervarsity Press, Downers Grove, IL.), 2005 and McGinn, "Apocalypse", who refers to the domesticating of Revelation in Greekspeaking Christianity. E. Ann Matter, "The Apocalypse in Early Medieval Exegesis", in R.K. Emmerson and B. McGinn (eds.), The Apocalypse in the Middle Ages (Cornell University Press, Ithaca, N.Y., 1992), p. 49 points out that the spiritual reading of the Apocalypse as an allegory of the church, did not eliminate eschatological expectations, more specifically of the return of the Antichrist.

49 Cf. Sean Michael Ryan, Hearing at the Boundaries of Vision: Education Informing Cosmology in Revelation 9 (T\&T Clark, London and New York, N.Y., 2012), pp. 147148. Cf. pp. 210-211 and especially his chapter 7 for the implications of Oecumenius' impressive erudition for the interpretation of Revelation.

50 His apologetic intent is evident already in the beginning of his commentary where he dates the writing of Revelation in the time of Domitian, the first-century Roman emperor and notes that 'a very long time, more than 500 years' expired before he wrote his commentary (Oec.1.2.6). 
and eschatological punishments as future events (Oec. 1.15; 2:17), ${ }^{51}$ but takes into consideration the changed political situation of his own time. His historical analysis of Revelation prepares for a different understanding of the text. Roman political leaders in earlier periods, he observes, had been evil emperors who had persecuted the church. Those evil rulers contrast with later ones. Constantine, whom he describes as a pious ruler and servant of God, is an example of the different character of later Roman rulers. ${ }^{52}$ In addition to this historical analysis, which allows him to speak positively about the rulers of his own time, he offers a consistent spiritual interpretation of Revelation. Some of the images in Revelation cannot be interpreted as literal references to historical figures and regalia in the first century. His spiritual reading is illustrated, amongst others, by his explanation of the thousand-year reign as referring to the earthly life of Christ (Oec. 11.3) through which God prevented the devil from opposing the Lord's miracles (Oec. 10.17.8). Also spiritual is his explanation of the heavenly Jerusalem as the church that dwells in the presence of God (Oec. 11.15-16). Following Irenaeus, he argues that the number 666 does not refer literally to one specific Roman Emperor, as had often been suggested in earlier times. It now takes on a spiritual character as indication of evil opponents of God in various contexts who must be identified by believers in terms of their own situations (Oec. 8.5.6; cf. Oec. 5.30.3), naming as examples 'especially' Lampetis, Benediktos and Titan. ${ }^{53}$

These examples illustrate how Revelation is interpreted in terms of spiritual theme and matters. And yet, these spiritual readings cannot be separated

51 Cf. for a full discussion, Pieter G. R. de Villiers, "History, Mysticism and Ethics in Oecumenius: A Hermeneutical Perspective on the Earliest Extant Greek Commentary on Revelation" in SHE 33 (2007), 315-336 and Pieter G. R. de Villiers, "The Understanding of Violence in Oecumenius' Greek Commentary on Revelation". Acta Patristica et Byzantina 20 (2009): 232-245. The seven hills which are said to be seven kings in Revelation 17:9-11 "is a very clear indication that he (John) is speaking about Rome, for Rome is described as seven crested, and no other city is so called." The kings are seven of the "very many emperors of Rome" (Oec. 9.12.3).

52 In his comments on Revelation 17:9-14 Oecumenius lauds the emperor as the pious Constantine who changed the policies of the early Roman Empire that sought to persecute Christians (Oec. 9.13.5-6) that took place in the time of the emperor Domitian' (Oec. 2.13.9). But believers were also persecuted by other emperors (Oec. 9.12.3).

53 For a further discussion, cf. De Villiers, “History”, p. 336. 
from the political context in which they functioned and from their political implications. They were offered by established figures within the church who had a vested interest in avoiding readings that would threaten the church's relationship with the state. They spiritualized the message of Revelation through their non-literal readings because they wanted to protect the privileged position that the church had attained after the relationship between Christianity and the state was normalized. They reinterpreted the literal reading of Revelation in terms of the Roman Empire and historical figures, to relate it to the spiritual condition of the church in their own times. These spiritual readings thus reflect power relationships and power games and are deeply political in their very essence and nature.

\section{Conclusion}

This overview reveals that political readings of Revelation have existed from very early times until the present day. The book has been understood in various ways: readers have read it literally as predictions of future events, characters and institutions. On the other hand, the book has been read spiritually, as referring to spiritual themes and contents that transcend the particular and specific. Seen from this perspective these spiritual readings can be described as symbolic or even metaphorical.

Both these readings reflect the times and contexts of those who proposed them, reflecting the desire to address the religious needs of their audiences. This is true, even of eschatological readings that have devastating socio-political implications. As recent research has suggested, even failed predictions of the world's end can express "profound hopes and disappointments...that stir the soul and produce lasting and powerful religions of salvation." ${ }^{54}$

Both these traditions read Revelation so differently that one wonders whether they are talking about the same text. They indicate that no homophonic approach to Revelation is possible. These different voices attest to its open nature and contents. One should acknowledge, defend and even celebrate the polyphonic character of its reception history, which reflects the book's continuing relevance for later audiences. And yet, the overview

54 Landes, Introduction, p. 10. 
alerts the modern critic to the fact that the reception history of Revelation in some cases attests to darker times in which the transformative power of the text is seriously endangered by the self-interest and self-promotion of its interpreters. The litmus test is to discover how to avoid reading the book in such a way that polyphonic voices degenerate into a cacophony of violent, abusive noises lacking transformative power. This is even more important in the light of Revelation's powerful political potential.

\section{Bibliography}

Adler, William. "The Apocalyptic Survey of History Adapted by Christians: Daniel's Prophecy of 70 Weeks", in James VanderKam and William Adler (eds.), The Jewish Apocalyptic Heritage in Early Christianity. Compendia Rerum Judaicarum ad Novum Testamentum, Section 3. Jewish Traditions in Early Christian Literature (Van Gorcum, Assen; Minneapolis, MI., Fortress Press, 1996), 201-237.

Adler, William. "Early Christian Historians and Historiography", in S.A. Harvey and David C. Hunter (eds.), The Oxford Handbook of Early Christianity (Oxford University Press, Oxford, 2008), 584-602.

Beale, G.K. The Book of Revelation. NIGTC (Eerdmans, Grand Rapids, MI.).

Boesak, Allan A. Farewell to Innocence: A Socio-Ethical Study on Black Theology and Black Power (Orbis Books, Maryknoll, 1976).

Boesak, Allan A. Comfort and Protest. The Apocalypse from a South African Perspective (Westminster Press, Philadelphia, P.A.), 1987, 13.

Boxall, Ian. The Revelation of St. John. Black's New Testament Commentaries (Continuum, London, 2006).

Boyer, Paul S. "John Darby meets Saddam Hussein: Foreign policy and Bible". The Chronicle of Higher Education, 13 February 2003: B10-11.

Brandon, Benjamin David. "Eusebius of Caesarea's Oration in Praise of Constantine as the Political Philosophy of the Christian Empire" (M. A Thesis, Boise State University, December 2012). 
Cerrato, JA. Hippolytus between East and West: Provenance of the Corpus (Oxford University Press, Oxford, 2002).

Clouse, Robert G. “The Danger of Mistaken Hopes”, in Carl E. Armstrong, W. Ward Gasque (eds.). A Guide to Biblical Prophecy (Wipf and Stock, Eugene, OR., 2001), 29-30.

Collins, Adela Yarbro. "Persecution and Vengeance in the Book of Revelation," in David Hellholm (ed.), Apocalypticism in the Mediterranean World and the Near East (Mohr Siebeck, Tübingen, 1983), 729-748.

De Villiers, Pieter GR. "History, Mysticism and Ethics in Oecumenius: A Hermeneutical Perspective on the Earliest Extant Greek Commentary on Revelation", in SHE 33 (2007), 315-336.

De Villiers, Pieter GR. "The Understanding of Violence in Oecumenius' Greek Commentary on Revelation". Acta Patristica et Byzantina 20 (2009): 232-245.

De Villiers, Pieter GR. “Towards a Spirituality of Peace”. Acta Theologica Supplementum 11 (2008), 20-58.

Droge, Arthur J. Homer or Moses? Early Christian Interpretations of the History of Culture (J.C.B. Mohr (Paul Siebeck) Verlag, Tübingen), 1989.

Ferguson, Everett. The Early Church at Work and Worship. Vol. 2, Catechesis, Baptism Eschatology and Martyrdom (Cascade Books, Eugene, OR., 2014), 213-243.

Fredriksen, "P. Tyconius and Augustine on the Apocalypse", in R.K.

Emmerson and B. McGinn (ed.), The Apocalypse in the Middle Ages (Cornell University Press, Ithaca, N.Y., 1992), 20-37.

Gribben, Crawford. Writing the Rapture; Prophecy Fiction in Evangelical America (Oxford University Press, Oxford, 2009), 129-144.

Hill, Charles Evan. Regnum Caelorum: Patterns of Millennial Thought in Early Christianity (Eerdmans, Grand Rapids, 2001).

Hughes, Kevin L. Constructing Antichrist: Paul, Biblical Commentary, and the Development of Doctrine in the Early Middle Ages (The Catholic University Press, Washington D.C., 2005). 
Jewett, Robert. Jesus Against the Rapture. Seven Unexpected Prophecies (The Westminster Press, Philadelphia, 1979).

Klein, Ralph W. "Anti-Semitism as Christian Legacy: The Origin and Nature of our Estrangement from the Jews". Currents in Theology and Mission 11 (1984): ): 285-301.

Landes, Richard Allen, Andrew Colin Gow, David C. Van Meter (eds.), The Apocalyptic Year 1000: Religious Expectation and Social Change, 950-1050 (Oxford University Press, Oxford, 2003).

Landes, Richard Allen "Introduction: The Terribles Espoirs of 1000 and the Tacit Fears of 2000", in Richard Allen Landes, Andrew Colin Gow, David C. Van Meter (eds.), The Apocalyptic Year 1000: Religious Expectation and Social Change, 950-1050 (Oxford University Press, Oxford, 2003), 3-16.

Maier, Gerhard. Die Johannesoffenbarung und die Kirche. WUNT 25 (J.C.B. Mohr, Tübingen, 1981).

Maier, Harry O. Apocalypse Recalled. The Book of Revelation after Christendom (Fortress Press, Minneapolis, MI.), 1-7.

Matter, E Ann. “The Apocalypse in Early Medieval Exegesis", in R.K. Emmerson and B. McGinn (eds.), The Apocalypse in the Middle Ages (Cornell University Press, Ithaca, N.Y., 1992), 38-50.

Bernard McGinn, "Introduction: John's Apocalypse and the Apocalyptic Mentality", in Richard K. Emmerson and Bernard McGinn (eds.), The Apocalypse in the Middle Ages (Cornell University Press, Ithaca and London 1992), 3-19.

Meier, Mischa. „Eschatologie und Kommunikation im 6. Jahrhundert n. Chr. - oder: Wie Osten und Westen beständig aneinander vorbei redeten", in Wolfram Brandes and Felicitas Schmieder (Hrsgg.), Endzeiten. Eschatologie in den monotheistischen Weltreligionen. Millennium-Studien zu Kultur und Geschichte des ersten Jahrhunderts n. Chr. 16 (De Gruyter, Berlin/New York 2008), 41-73.

Miles, Margaret R. Rereading Historical Theology: Before, During, and After Augustin (Cascade Books, Eugene, OR., 2008), 79-80. 
Osiek, Carolyn. The Feminist and the Bible: Hermeneutical Alternatives (Scholars Press, Chicago, 1985).

Ryan, Sean Michael. Hearing at the Boundaries of Vision: Education Informing Cosmology in Revelation 9 (T\&T Clark, London and New York, N.Y., 2012).

Schneiders, Sandra. The Revelatory Text: Interpreting the New Testament as Sacred Scripture (HarperSanFrancisco, San Francisco, 1991).

Rossing, Barbara R. The Rapture Exposed: the Message of Hope in the Book of Revelation (Westview Press, Boulder, CO., 2004).

Rubenstein, Jay. Armies of Heaven: The First Crusade and the Quest for Apocalypse (Basic, New York, 2011).

Taborn, James. "Ancient Jewish and Early Christian Millennialism", in Catherine Wessinger (ed.), The Oxford Handbook of Millennialism (Oxford University Press, Oxford, 2016), 152-267.

Van Asselt, WJ. "Chiliasm and Reformed Eschatology in the Seventeenth and Eighteenth Centuries", in A. van Egmond \& D van Keulen (eds.), Christian Hope in Context. Studies in Reformed Theology. 4 (Meinema, Zoetermeer, 2001), 11-29.

Veldt, S Mark. "Attitudes toward the Jews in the Earliest Centuries A.D.", 2007. Dissertations. Paper 925. [Online] Available: (http://scholarworks. wmich.edu/cgi/viewcontent.cgi?article=1927\&context=dissertations) [Accessed 24 February 2017].

Verbeke, Werner, Daniel Verhelst and Andreas Welkenhuysen (Hrsg.), The Use and Abuse of Eschatology in the Middle Ages. ML.St 15 (Peeters, Leuven, 1988), 137-211.

Walraff, Martin (Hrsg.), Julius Africanus und die christliche Weltchronik (Walter de Gruyter, Berlin, New York, 2006).

Wallraff, Martin (ed.), Iulius Africanus Chronographiae. The Extant Fragments (De Gruyter, Berlin, 2007).

Weinrich, William C. Revelation. Ancient Christian Commentary on Scripture 12. (Intervarsity Press, Downers Grove, IL, 2005). 